\title{
Porcine oviduct sperm binding glycoprotein and its deleterious effect on sperm: a mechanism for negative selection of sperm?
}

\author{
Juan M. Teijeiro', Dora G. Dapino² and Patricia E. Marini ${ }^{1,3^{*}}$ \\ ${ }^{1}$ Instituto de Biología Molecular y Celular de Rosario (IBR-CONICET) y Área Biología, Facultad de Ciencias Bioquímicas y Farmacéuticas. UNR. \\ ${ }^{2}$ Cátedra de Fisiología. Facultad de Ciencias Veterinarias. UNR. \\ ${ }^{3}$ Member of the research career (CIC-UNR).
}

\begin{abstract}
In their journey through the oviduct some subpopulations of sperm are preserved in a reservoir, while others are negatively selected. Sperm binding glycoprotein (SBG) is a pig oviductal epithelial cell glycoprotein that produces, under capacitating conditions, acrosome alteration, p97 tyrosine-phosphorylation and reduction of the motility of sperm. In this paper, we show that SBG is accessible at the extracellular surface of the oviductal epithelial cells, supporting a sperm interaction biological role in situ. We analyze the possible dependence of the tyrosine-phosphorylation of p97 on the PKA mechanism, finding that apparently it is not PKA dependent. Also, after SBG treatment the phosphorylated proteins locate mainly at the detached periacrosomal region and at the tail of sperm; the latter may be related to SBG's motility reduction effect. The study of the time course effect of SBG on sperm as detected by chlortetracycline (CTC) staining and of its binding to sperm by immunodetection in conjunction with CTC, shows results in agreement with the hypothesis that this glycoprotein is involved in the alteration of acrosomes in a specific sperm subpopulation. The results suggest that SBG may be part of a mechanism for negative selection of sperm.
\end{abstract}

Key words: acrosome alteration, tyrosine-phosphorylation.

\section{INTRODUCTION}

The oviduct is a dynamic organ in which final gamete maturation takes place. The interaction between sperm and the oviduct results in a mechanism by which a subpopulation of sperm is stored forming a sperm reservoir. The formation of a sperm reservoir is a widespread process that ensures the availability of a suitable number of viable spermatozoa for fertilization (Tienthai et al., 2004) and has been shown for a variety of mammals including sheep (Hunter and Nichol, 1983), mice (Suárez, 1987; Kan and Esperanzate, 2006), hamsters (Smith and Yanagimachi, 1991; Kan and Esperanzate, 2006), cows (Hunter et al., 1991; Kan and Esperanzate, 2006), rats (Orihuela et al., 1999) and pigs (Hunter, 1981). This process includes spermatozoa binding to oviductal epithelial cells via the plasma membrane overlying the acrosome (Gualtieri and Talevi, 2000) in a carbohydrate recognition dependent way (DeMott et al., 1995; Lefebvre et al., 1997; Suárez, 2001; Wagner et al., 2002). The sperm proteins that have been assigned a function in sperm reservoir formation are spermadhesins DQH (Manaskova et al., 2007) and AQN1 (Ekhlasi-Hundrieser et al., 2005) in pig; and PDC109 (BSPA1/A2), BSPA3, and BSP30K in bull (Gwathmey et al., 2006). The oviductal proteins that have been related to this process are annexins A1, 2, 4 and 5 in cow (Ignotz et al., 2007) and annexin A2 in pig (Teijeiro et al., 2009). It is known that adhesion of sperm to form a reservoir occurs only for selected subpopulations that include sperm with intact acrosomes in cow (Gualtieri and Talevi, 2000); at an uncapacitated status for horse (Thomas et al., 1994), cow (Lefebvre and Suarez, 1996) and pig (Fazeli et al., 1999); with low internal free calcium content and reduced membrane protein phosphorylation for pigs and bovines (Petrunkina et al., 2001; Gualtieri et al., 2005); of superior morphology for horse (Thomas et al., 1994); and with normal chromatin structure for human and pig (Ellington et al., 1999; Ardón et al., 2008). Spermatozoa selected through oviductal adhesion have superior zona pellucida binding and fertilization ability (Gualtieri and Talevi, 2003). Detachment from the oviduct has been linked to protein loss upon capacitation (TöpferPetersen et al., 2008), to hyperactivated motility (De Mott and Suárez, 1992; Pacey et al., 1995) and to protein disulfide reduction (Gualtieri et al., 2009). However, this would be only one of the forms of sperm-oviduct interaction as, in vivo, an apparent negative selection of sperm seems to occur in this organ. This selection remains a poorly studied event, but sperm subpopulations with altered plasma membranes have been detected in the lumen of the oviduct (Mburu et al., 1997; Tienthai et al., 2004). Interestingly, porcine sperm binding glycoprotein (SBG), which produces an acrosomal alteration effect on sperm incubated under capacitating conditions (Teijeiro et al., 2008), localizes to the apical surface of cells at the lumen of the oviduct, as determined by immunohistochemistry (Pérez et al., 2006). SBG was first isolated due to its capacity of association to sperm periacrosomal membranes; it shows an apparent molecular mass higher than $220 \mathrm{kDa}$ and exposes Galß1-3GalNAc (Marini and Cabada, 2003). SBG produces alteration of pig sperm acrosome integrity, suppression of motility and tyrosine phosphorylation of a $97 \mathrm{kDa}$ protein on spermatozoa (p97) (Teijeiro et al., 2008). These data lead us to propose that SBG is involved in sperm negative selection, producing its deleterious effect on sperm that suffer the capacitation process while being in the oviduct (Teijeiro et al., 2008). In this work we aim to advance on the characterization of SBG's location, effect and mechanism of action. 


\section{MATERIALS AND METHODS}

\section{Chemical}

Unless otherwise stated, chemicals were obtained from SigmaAldrich (Argentina).

\section{Semen collection and treatments}

Semen was collected from adult boars of proven fertility and routinely used for artificial insemination (AI) by the glove-hand method. Sperm rich fraction was diluted in Cronos (Laboratorio Medi Chimica, Reggio Emilia, Italy), and conserved at $16^{\circ} \mathrm{C}$ until use (no more than 24 hours from collection). Quality of the samples was established by evaluating motility, viability, concentration, acrosomal and morphological parameters (Althouse, 1997).

Spermatozoa were recovered by centrifugation at $700 \mathrm{~g}$ for 5 minutes and washed twice in Tyrode's capacitating medium, TALP (Parrish et al., 1988), which contains $96 \mathrm{mM} \mathrm{NaCl}, 3.1$ $\mathrm{mM} \mathrm{KCl}, 2.0 \mathrm{mM} \mathrm{CaCl}, 0.4 \mathrm{mM} \mathrm{MgSO}_{4}, 0.3 \mathrm{mM} \mathrm{NaH} \mathrm{PO}_{4}, 20$ $\mathrm{mM}$ HEPES, $21.6 \mathrm{mM}$ sodium lactate, $1 \mathrm{mM}$ sodium pyruvate, $15 \mathrm{mM} \mathrm{NaHCO}{ }_{3}, 5 \mathrm{mM}$ glucose, 285-315 mOsm. The sperm were resuspended to give a final concentration of $10^{7} \mathrm{sperm} / \mathrm{ml}$ in the same medium.

SBG purification

SBG was purified as reported by Marini and Cabada (2003). Briefly, oviducts of gilts were obtained at a local abattoir and transported to the laboratory in ice-cold PBS. The isthmic section was separated and opened longitudinally. Epithelial cells were obtained by scraping with the blunt side of a scalpel blade, disaggregated, washed and disrupted in Potter homogenizer. Fractions enriched in plasma membrane were prepared by differential centrifugation. Extracts of these fractions were obtained by incubation in $0.5 \mathrm{M} \mathrm{NaCl}-0.2 \%$ Triton X100 - $10 \mathrm{mM}$ Tris- $\mathrm{HCl} \mathrm{pH} 7.5$ for $1 \mathrm{~h}$ at $4^{\circ} \mathrm{C}$. After centrifugation at $105,000 \mathrm{~g}$ for $1 \mathrm{~h}$ at $4^{\circ} \mathrm{C}$, the supernatants were dialyzed against TALP and used for affinity chromatography.

The affinity chromatography column was prepared by coupling of a fraction of boar sperm enriched in components from the periacrosomal and acrosomal external membranes to Sepharose CL4B (Marini and Cabada, 2003). Oviductal cell membrane extracts prepared as indicated above were applied and, after washing, elution was achieved with $0.5 \mathrm{M} \mathrm{NaCl}-10$ $\mathrm{mM}$ Tris- $\mathrm{HCl} \mathrm{pH}$ 7.5. Only one protein peak was found on the bound fraction by measure of Absorbance at $280 \mathrm{~nm}$. Purification of the native form of SBG was confirmed by SDS-PAGE on $5-12 \%$ polyacrylamide gradient gels according to Laemmli (1970); followed by silver staining (Rabilloud, et al. 1994).

\section{In situ biotinylation of oviductal lumen}

The biotinylation protocol was based on the method described by Holt et al. (2005). Batches of ten oviducts were trimmed from reproductive tissues and washed in ice-cold PBS. The isthmus section of each oviduct was separated, flushed with $2 \mathrm{ml}$ of ice-cold PBS/CM (PBS containing $1.3 \mathrm{mM} \mathrm{CaCl}_{2}$ and $1 \mathrm{mM}$ $\mathrm{MgCl}_{2}, \mathrm{pH}$ 7.2) and then with $2 \mathrm{ml}$ of biotinylating reagent EZLink® Sulfo-NHS-SS-Biotin (Pierce, Thermo Scientific, USA) at $0.5 \mathrm{mg} / \mathrm{ml}$ in PBS/CM. The isthmic sections were clamped at each end, filled with the same solution and incubated $30 \mathrm{~min}$ at room temperature. After incubation, isthmus sections were emptied and the excess of biotin was inactivated by flushing with quenching solution (Pierce, Thermo Scientific, USA). One isthmus section of each batch was fixed in $4 \%$ formaldehyde and then processed to detect biotinylated proteins on tissue sections. In brief, tissue was dehydrated, embedded in paraffin, cut into $5 \mu \mathrm{m}$ sections, and mounted on slides optimized for immunohistochemistry (Frosted HiFix ${ }^{\mathrm{NH}}$, TNT, Argentina). The other oviduct sections were opened longitudinally and epithelia were scraped with the blunt side of a scalpel blade and transferred to a $50 \mathrm{ml}$ conical tube. Scraped cells were rinsed three times with $5 \mathrm{ml}$ of TBS $(25 \mathrm{mM}$ Tris- $\mathrm{HCl}, \mathrm{pH} 7.4$, $150 \mathrm{mM} \mathrm{NaCl}$ ) by centrifugation at $500 \mathrm{~g}$ for $3 \mathrm{~min}$ at $4^{\circ} \mathrm{C}$. After rinsing, scraped cells were resuspended in lysis buffer (Pierce, Thermo Scientific, USA) and sonicated at $1.5 \%$, five 1 -second bursts. Cells were incubated $30 \mathrm{~min}$ on ice, vortexing every $5 \mathrm{~min}$ for $5 \mathrm{sec}$ and then centrifuged at 10,000 $\mathrm{g}$ for 2 minutes at $4^{\circ} \mathrm{C}$. Biotinylated proteins were purified by affinity to NeutrAvidin ${ }^{\mathrm{TM}}$ Agarose (Pierce, Thermo Scientific, USA) according to manufacturer's instructions.

Detection of biotinylated proteins and SBG on nitrocellulose membranes

Purified biotinylated proteins were separated in 5-12\% SDSPAGE and transferred to nitrocellulose membranes (GE Healthcare, Argentina) using Miniprotean 3 System (Bio-Rad, Hercules, CA). For biotinylated proteins detection, blots were incubated with $1 \mu \mathrm{g} / \mathrm{ml}$ peroxidase-conjugated streptavidin. For SBG detection, nitrocellulose membranes were incubated with 1:1000 anti-SBG (Pérez et al., 2006) and then with the second antibody (anti-rabbit IgG-horseradish peroxidase, GE Healthcare, UK) $1: 10,000 \mathrm{v} / \mathrm{v}$ in TBS. In both cases labeled proteins were revealed using enhanced chemiluminescence detection with ECL Kit (GE Healthcare, Argentina) according to manufacturer's instructions. An aliquot of purified biotinylated proteins was resolved by $5-12 \%$ SDS-PAGE and visualized by silver staining.

\section{Detection of biotinylated proteins on tissue sections}

Tissue sections were deparaffinized in xylene, then rehydrated through graded dilutions of ethanol $(100 \%, 95 \%, 70 \%$, and $35 \%$ ), followed by two washes in PBS. Endogenous peroxidases were inactivated by incubating slides for $30 \mathrm{~min}$ in $3 \% \mathrm{H}_{2} \mathrm{O}_{2}$ in methanol, followed by three 5-min washes in PBS. Slides were incubated $1 \mathrm{~h}$ with $10 \mu \mathrm{g} / \mathrm{ml}$ peroxidase-conjugated streptavidin and peroxidase activity was visualized by development with 3,3'-diaminobenzidine tetrahychloride (DAB).

\section{Evaluation of the effect of SBG on sperm by CTC staining}

Sperm were suspended in TALP supplemented with the indicated amounts of SBG $(0,100 \mu \mathrm{g} / \mathrm{ml}, 150 \mu \mathrm{g} / \mathrm{ml})$ and with fetuin as specificity control. This protein was chosen because it does not contain Gal $\beta 1-3 \mathrm{GalNAc}$, the disaccharide exposed by SBG, which could be at least partially responsible for its biological effect. The concentrations of SBG used were based on studies of Berger et al. (1989) and Melendrez et al. (1994), for solubilized ZP as acrosomal inducers and previous work by us (Teijeiro et al., 2008) at lower concentrations (up 
to $50 \mu \mathrm{g} / \mathrm{ml}$ give similar results, unpublished data). Samples were incubated at $37^{\circ} \mathrm{C}$ in a $5 \% \mathrm{CO}_{2}$ atmosphere. At the times stated in each case an aliquot of sperm was examined by CTC staining as described by Dapino et al. (2006). In brief, CTC (750 $\mu \mathrm{M})$ was prepared in $20 \mathrm{mM}$ Tris buffer containing $130 \mathrm{mM}$ $\mathrm{NaCl}$ and $5 \mathrm{mM}$ DL-cysteine (final $\mathrm{pH}$ 7.8). Sperm suspensions $(5 \mu 1)$ were mixed with $5 \mu \mathrm{l}$ of CTC solution on a warmed slide $\left(37^{\circ} \mathrm{C}\right)$. After $30 \mathrm{sec}, 5 \mu \mathrm{l}$ of $0.2 \%$ glutaraldehyde in 0.5 $\mathrm{M}$ Tris pH 7.4, were added. Finally, $5 \mu \mathrm{l}$ of $0.22 \mathrm{M} \mathrm{1,4-diaza-}$ byciclo (2.2.2) octane (DABCO) in 50\% glycerol were added to retard fluorescence fading. After adding a coverslip, slides were gently compressed using a tissue paper. The slides were then sealed along the edges with colorless nail varnish and examined with a microscope equipped with epifluorescence (Olympus BH2 Company Ltd., Tokyo, Japan). At least 100 cells were counted. Sperm viability was analyzed by eosin-nigrosin staining method and was at least of $75 \%$ after $1 \mathrm{~h}$ of incubation, which are the rates usually found for pig sperm.

\section{Detection of SBG binding sites on sperm stained with CTC}

Sperm were incubated in TALP in the presence of $150 \mu \mathrm{g} / \mathrm{ml}$ of SBG for $1 \mathrm{~h}$ at $37^{\circ} \mathrm{C}$. Five microlitres of sperm suspensions were mixed with $5 \mu \mathrm{l}$ of CTC solution on slides, then $5 \mu \mathrm{l}$ of $0.2 \%$ glutaraldehyde in $0.5 \mathrm{M}$ Tris $\mathrm{pH} 7.4$ were added and slides were air dried in darkness. The slides were gently rinsed with PBS twice, blocked with $2 \%$ bovine serum albumin - $0.2 \%$ Triton X100 in PBS for $60 \mathrm{~min}$ and then treated with the primary antibodies overnight at $4^{\circ} \mathrm{C}$. Antibodies were polyclonal anti-SBG (1:50) (Pérez et al., 2006). After being rinsed twice with PBS, the slides were treated with Cy3 conjugated anti-rabbit immunoglobulin (Chemicon International, Inc. USA) (1:750) for $60 \mathrm{~min}$. After rinsing twice with PBS, the slides were covered with $0.22 \mathrm{M}$ DABCO dissolved in $50 \%$ glycerol and cover slips. Alternatively, sperm suspensions were incubated $1 \mathrm{~h}$ with $150 \mu \mathrm{g} / \mathrm{ml}$ of SBG, then 30 min with polyclonal anti-SBG antibodies (1:50), air dried and then incubated $1 \mathrm{~h}$ with Cy3 conjugated anti-rabbit immunoglobulin (Chemicon International, Inc. USA) (1:750). After incubation, $5 \mu \mathrm{l}$ of sperm suspension were mixed with $5 \mu \mathrm{l}$ of CTC solution on slides, fixed and coverslip mounted with $5 \mu$ l of $0.22 \mathrm{M} \mathrm{DABCO}$ in $50 \%$ glycerol. For both protocols, slides were examined with microscope equipped with epifluorescence, counting at least 100 cells.

\section{Detection and localization of phosphotyrosine containing polypeptides}

Sperm suspensions were incubated for 1 hour at $37^{\circ} \mathrm{C}$ in a $5 \%$ $\mathrm{CO}_{2}$ atmosphere in TALP, and one aliquot was then treated with $10 \mu \mathrm{M}$ calcium ionophore A23187. Additionally, a sample was incubated for $30 \mathrm{~min}$ in TALP supplemented with 50 $\mu \mathrm{M}$ of H89 PKA inhibitor and then $1 \mathrm{~h}$ with SBG at a final concentration of $150 \mu \mathrm{g} / \mathrm{ml}$. Another aliquot was incubated in TALP containing $150 \mu \mathrm{g} / \mathrm{ml}$ of SBG. Cells $\left(1 \times 10^{6} \mathrm{sperm}\right)$ from each treatment were used for protein separation on $12 \%$ SDSPAGE and proteins transferred to nitrocellulose membranes. Transferred proteins were visualized in the membrane by Pounceau S staining. Nonspecific binding sites were blocked by incubation with 5\% dry non-fat milk in TBS. Membranes were treated with anti-phosphotyrosine monoclonal antibodies (clone 4G10, Upstate, Lake Placid, NY, USA) 1:2000 in TTBS (TBS plus $0.5 \%$ Tween 20) overnight at $4^{\circ} \mathrm{C}$. After washing (three times for $10 \mathrm{~min}$ each), the blot was incubated with peroxidase-conjugated goat anti-mouse antibodies at 1:2000 in TTBS for $120 \mathrm{~min}$ and washed again. Labeled proteins were revealed using enhanced chemiluminescence detection with ECL Kit (GE Healthcare, Argentina) according to manufacturer's instructions.

Aliquots of $5 \mu \mathrm{l}$ of sperm incubated with SBG, in TALP or non-incubated were smeared on slides, fixed with glutaraldehyde and air dried. Sperm were permeabilized by 30 min incubation in methanol, except when indicated. After blocking non-specific binding sites with 5\% dry non-fat milk in TBS the slides were incubated with anti-phosphotyrosine monoclonal antibodies (1:100) overnight at $4^{\circ} \mathrm{C}$. The primary antibodies were revealed with goat anti-mouse Alexa Fluor ${ }^{\circledR}$ 488-conjugated IgG (Invitrogen, Argentina) at 1:100 dilution. At least 100 cells were observed using an epifluorescence microscope.

\section{Statistical analysis}

The normality assumptions of data were studied by skewness and Kurtosis coefficients, normality plot and Wilk-Shapiro test. Percentages of spermatozoa with altered acrosomes (AA) and capacitated were subjected to two-way analysis of variance (ANOVA). When F-test results were significant in ANOVA, individual means were further tested by Tukey's multiple range test (Motulsky, 1995).

\section{RESULTS}

Accessibility of SBG at the extracellular surface of oviductal epithelial cells

An experimental strategy for studying surface-exposed proteins involved in porcine sperm-oviduct contact interactions was validated by Holt et al. (2005). This strategy was used to verify whether SBG is exposed on the surface of oviductal cells. The localization of this glycoprotein at the extracellular surface of isthmic epithelial cells would be an indication of its possible role. Using this strategy, superficial isthmic proteins were labeled with biotin in situ, and purified by affinity chromatography. Western blotting was performed on purified biotinylated proteins with anti-SBG antibodies. SBG was detected among the biotin-labeled purified proteins (Fig. 1A). Histochemistry of the in situ biotinylated proteins, as a control for possible intracellular biotinylation, confirmed the absence of biotinylated proteins in the cytoplasm of the cells (Fig. 1B and D). Immunolocalization of SBG in order to compare the localization of biotinylated protein and the localization of SBG is shown (Fig. 1C).

Effect of SBG over sperm as determined by Chortetracycline staining (CTC)

We have previously reported SBG induced acrosome alteration (AA) after $1 \mathrm{~h}$ of incubation of sperm under capacitating conditions detected by Wells and Awa staining (Teijeiro et al., 2008). This technique does not provide information about the capacitated sperm subpopulation. In order to obtain information about capacitated sperm, here we analyzed the effect of SBG by measuring the (CTC) patterns obtained at different times during $1 \mathrm{~h}$ of incubation. CTC staining allows the detection of sperm at initial steps of capacitation 
Interestingly, when SBG was present in the media, not only the patterns usually found (Wang et al., 1995) for intact (pattern F, Fig. 2A) acrosome-reacted (pattern AR, Fig. 2B) and capacitated sperm (pattern B, Fig. 2C) were seen, but also new patterns appeared in which the acrosome seems to be altered (Fig. 2D and E) and which are compatible with the images previously detected by Wells and Awa staining (Teijeiro et al., 2008). In these patterns, the detached periacrosomal membrane (Fig. 2D, bracket) or swelling (Fig. 2E, arrow) figures seen at the acrosomal region show fluorescence. Sperm showing these patterns were counted together with sperm showing pattern AR, which represented $4-7 \%$ sperm in every condition tested, to determine the rate of AA sperm.
When the time course effect was analyzed by CTC staining, at $40 \mathrm{~min}$ of incubation in capacitating conditions AA augmented slightly and to a same amount for $100 \mu \mathrm{g} /$ $\mathrm{ml}$ of SBG and for fetuin, used as a specificity control (see Material and Methods). A greater increase was seen for sperm incubated in the presence of $150 \mu \mathrm{g} / \mathrm{ml}$ SBG (Fig. 3A). At this time, a significant increase in pattern B (capacitated) of CTC staining was also noted for control sperm (Fig. 3B). After $1 \mathrm{~h}$ of incubation both concentrations of SBG produced a significant augment of AA with respect to the control, at a rate similar to the one previously detected by Wells and Awa staining (Teijeiro et al., 2008), the effect of $150 \mu \mathrm{g} / \mathrm{ml}$ of glycoprotein being greater than that of $100 \mu \mathrm{g} / \mathrm{ml}$ (Fig. 3A). At this time,

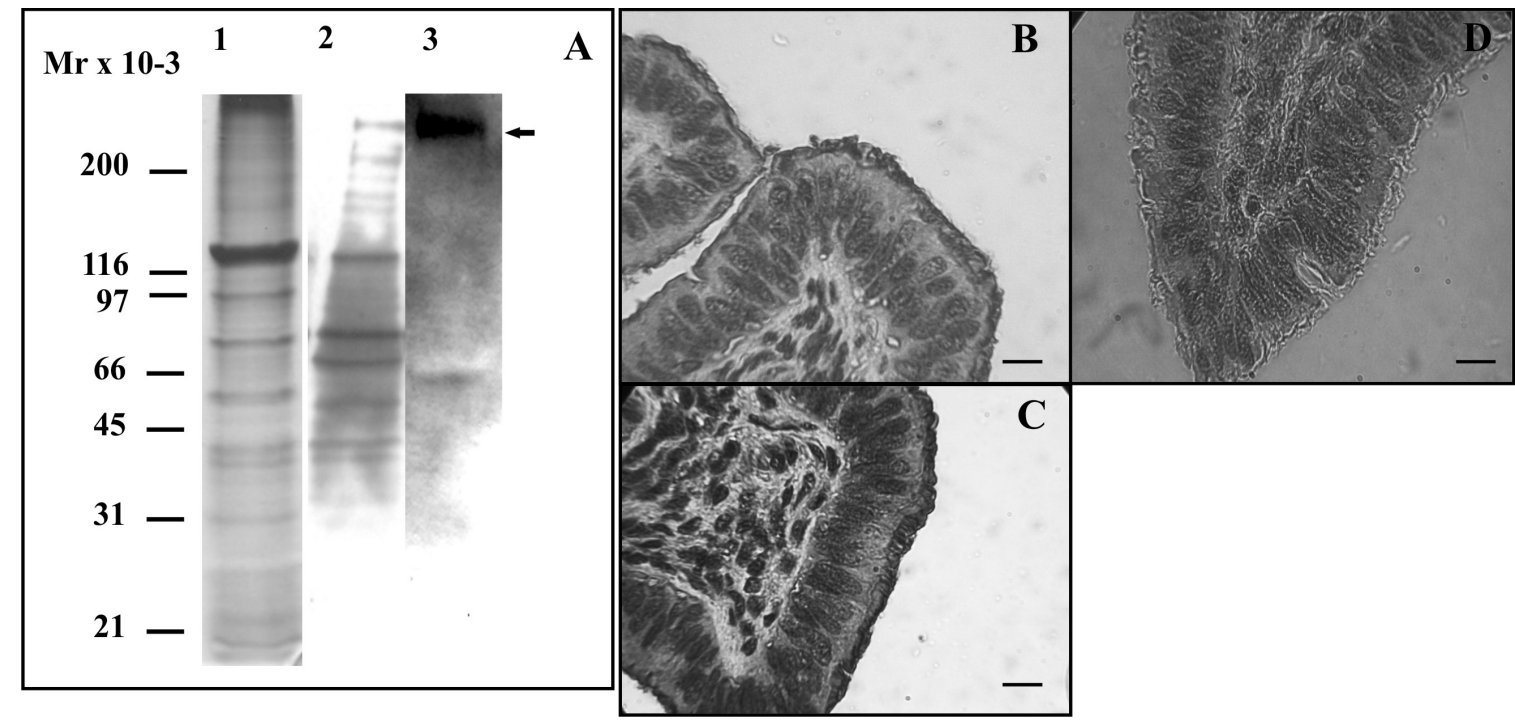

Figure 1. SBG localization to the extracellular surface of isthmus oviductal cells: Oviductal surface proteins were labeled with biotin. AProteins were purified by affinity to avidin and used for SDS-PAGE and western blot (15 $\mu \mathrm{g})$, followed by detection of 1- proteins by gel silver staining, 2- biotinylated proteins with streptavidin-peroxidase, 3- SBG with polyclonal anti-SBG antibodies (Arrow indicates SBG). BDetection of biotinylated proteins in isthmic tissue sections using streptavidin-peroxidase.C- Detection of SBG in oviductal epithelium using specific polyclonal antibodies. D- Negative control without biotinylating reagent of isthmic tissue sections. Scale bars represent $20 \mu \mathrm{m}$.

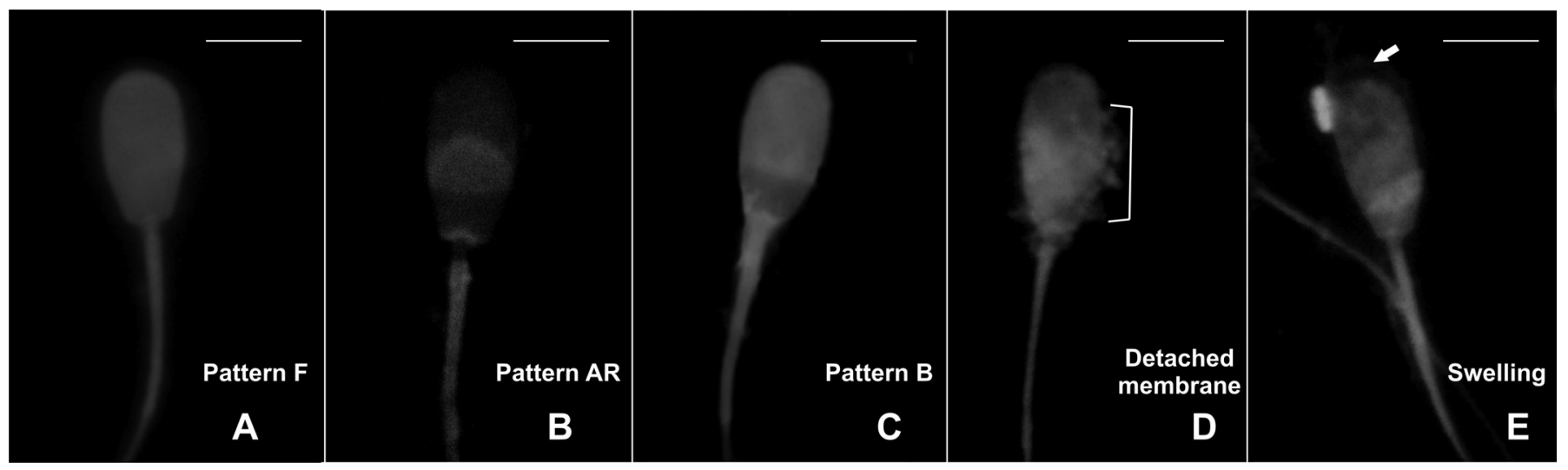

Figure 2. Patterns obtained by CTC staining of SBG treated sperm: Micrographs of sperm treated with SBG under capacitating conditions followed by CTC staining. A- pattern F, B- pattern AR, C- pattern B, D and E- AA patterns. The arrow indicates swelling and the bracket detached membranes. Scale bars represent $5 \mu \mathrm{m}$. 
however, the rate of pattern B (capacitated), augmented only for the fetuin containing control, reached $21.6 \%$. Surprisingly, when SBG was present, the rate of capacitated sperm did not vary throughout the whole experiment for $100 \mu \mathrm{g} / \mathrm{ml}$ of SBG, being the same of non-incubated samples. For $150 \mu \mathrm{g} /$ $\mathrm{ml}$ of glycoprotein, the rate of pattern B (capacitated) sperm diminished significantly after 1 hour of incubation, becoming lower than in capacitating medium without SBG (Fig. 3B). However, at least $3 \%$ pattern $\mathrm{B}$ sperm were detected at every time point in every condition used.

\section{Immunolocalization of SBG on CTC stained sperm}

In order to analyze the physiological state of sperm bound to SBG, the glycoprotein was detected by immunochemistry using anti-SBG specific antibodies on CTC-stained sperm after $1 \mathrm{~h}$ of incubation under capacitating conditions in the presence of $150 \mu \mathrm{g} / \mathrm{ml}$ of SBG. Alternatively, SBG detection was performed previous to CTC staining. The results obtained with both protocols were indistinguishable.

Most sperm (more than $79 \%$ ) presented a CTC pattern compatible with AA. All these sperm showed patches of SBG

A
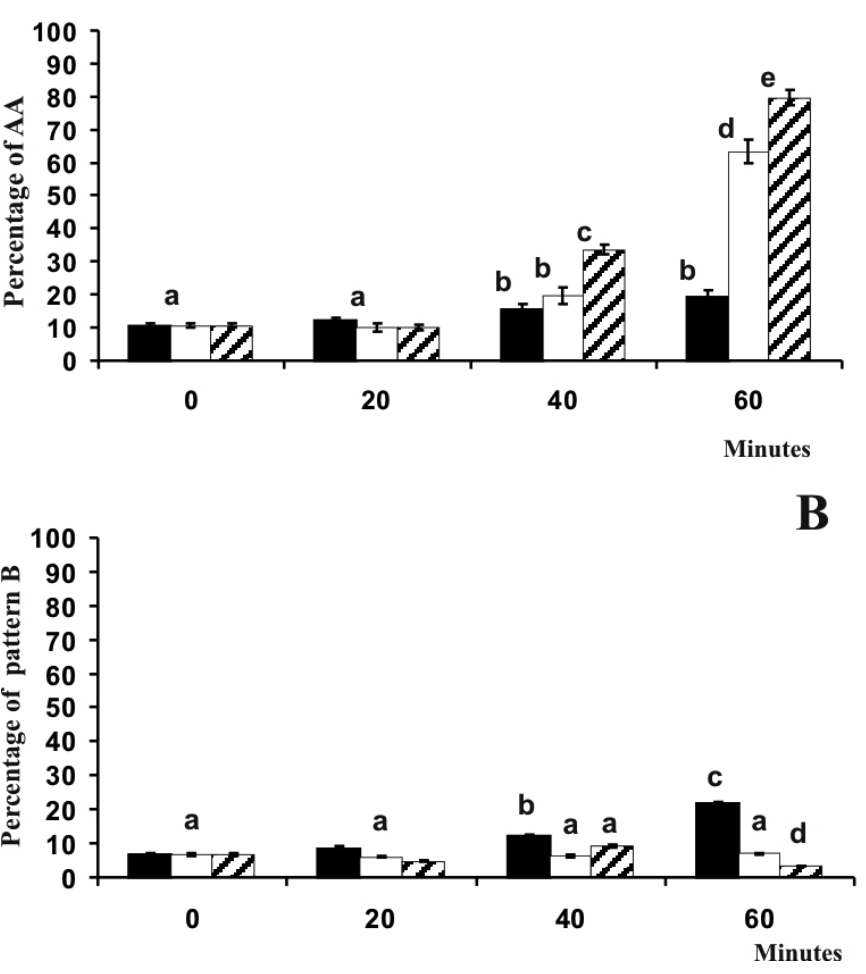

Figure 3. Rate of acrosomal alteration and capacitation produced by SBG as detected by CTC staining: Boar sperm were incubated in TALP for $1 \mathrm{~h}$ and the acrosomal state determined at different times by CTC staining. A- Percentage of AA, includes sperm showing acrosomal alterations plus acrosome reacted sperm. B- Pattern B sperm. Values are expressed as mean \pm SEM, values with different letters are significantly different, $\mathrm{n}=3, P<0.001$. Incubation was in TALP media containing $150 \mu \mathrm{g} / \mathrm{ml}$ of fetuin $(\bullet)$ and $100 \mu \mathrm{g} / \mathrm{ml}(\bigcirc)$ or $150 \mu \mathrm{g} / \mathrm{ml}(\oslash)$ of SBG. over the periacrosomal region by immunochemistry analysis (Fig. 4C and D). The rest of the sperm could be classified in two categories: the typical CTC pattern B (3.3\%), corresponding to capacitated sperm that did not exhibit bound SBG in any case; and CTC pattern F, compatible with unmodified sperm $(10.1 \%$ of total sperm) (Fig. 4A), which showed SBG bound to the whole periacrosomal region (Fig. 4B).

\section{The effect of SBG on $p 97$ tyrosine-phosphorylation}

SBG enhances the tyrosine-phosphorylation of a protein of apparent molecular mass $97 \mathrm{kDa}$ (p97) (Teijeiro et al., 2008). As the cAMP-dependent protein kinase A (PKA) has been associated with sperm capacitation, motility and acrosome reaction, we hypothesized that this protein may be related
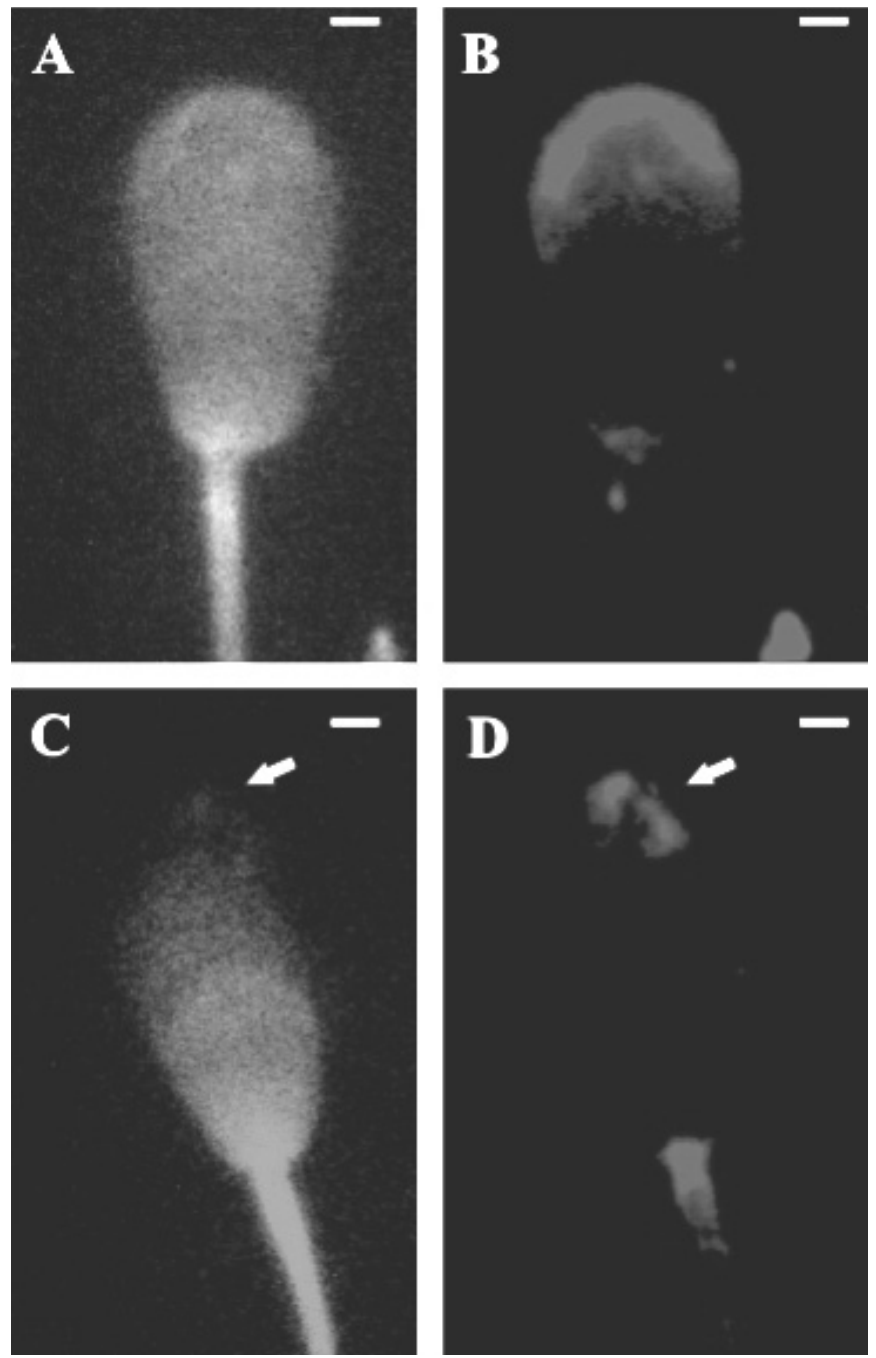

Figure 4. SBG immunolocalization on sperm showing different CTC patterns: Micrographs showing the different distribution of SBG (B, D) observed in CTC pattern F (A) and AA (C), respectively, after spermatozoa were incubated for 1 hour in TALP medium containing SBG $(150 \mu \mathrm{g} / \mathrm{ml})$ and revealed with anti-SBG polyclonal antibodies followed by Cy3 conjugated anti-rabbit immunoglobulin and CTC staining. Arrow indicates a fragment of periacrosomal membrane with bound SBG. Scale bar represents $1 \mu \mathrm{m}$. 
to the mechanism of p97 tyrosine-phosphorylation by effect of SBG. To test this possibility, sperm were incubated in the presence of $150 \mu \mathrm{g} / \mathrm{ml}$ SBG in TALP capacitating medium with and without prior treatment with the PKA inhibitor H89. As controls, sperm incubated in capacitating conditions in the absence of SBG and incubated in capacitating conditions followed by acrosome reaction induction with calcium ionophore A23187 were used. As shown in figure 5, H89 $(50 \mu \mathrm{M})$ did not affect p97 tyrosine-phosphorylation by SBG. Another concentration of H89 $(100 \mu \mathrm{M})$ was also tested, giving the same result (data not shown). The controls of capacitated and acrosome reaction induced sperm did not show p97 tyrosine-phosphorylation, and exhibited characteristic patterns, including the induction of p32 tyrosinephosphorylation in capacitated sperm (Fig. 5) (Dubé et al., 2005). Sperm in which acrosome reaction was induced by calcium ionophore did not show phosphorylated p32.

Cellular distribution of tyrosine-phosphorylated proteins upon SBG treatment

The localization of tyrosine-phosphorylated proteins on sperm was determined by immunocytochemistry. Non-incubated sperm showed signal mainly in the equatorial region (Fig. 6A) and sperm incubated in capacitating conditions showed the presence of tyrosine-phosphorylated proteins only in the acrosomal and equatorial regions (Fig. 6B). When sperm were incubated in the presence of $150 \mu \mathrm{g} / \mathrm{ml}$ SBG in capacitating conditions, tyrosine-phosphorylated proteins localized to the fragments of the altered or detached acrosomal membrane, and, in a small portion of the population to the flagellum (Fig. 6C). When the detection of tyrosine-phosphorylated proteins on SBG treated sperm was conducted without permeabilization, staining was limited to the periacrosomal detached fragments (Fig. 6C, inset). Controls without primary antibody showed no significant fluorescence (not shown).

\section{DISCUSSION}

SBG's localization in the regions of the oviduct surrounding the lumen and at the apical membrane of epithelial cells is a main consideration regarding its function. To be able to interact with sperm in their journey through this organ the glycoprotein should be accessible to sperm at the extracellular surface of the cells. Our previous results showing SBG's localization by immunohistochemistry (Pérez et al., 2006) did not deal with this task. The detection of SBG by a validated strategy for studying porcine oviductal surface-exposed protein (Fig. 1) establishes that the glycoprotein is accessible at the extracellular surface of the oviductal epithelial cells, where it may contact with sperm in vivo, supporting a possible role on sperm-oviduct interaction.

We have previously reported results concerning SBG's effect on acrosome alteration on sperm only when they are incubated in capacitating conditions. These results were based on observations made by Wells and Awa staining, that distinguishes between acrosome reacted and not reacted sperm, after progesterone stimulus. That is to say, only sperm

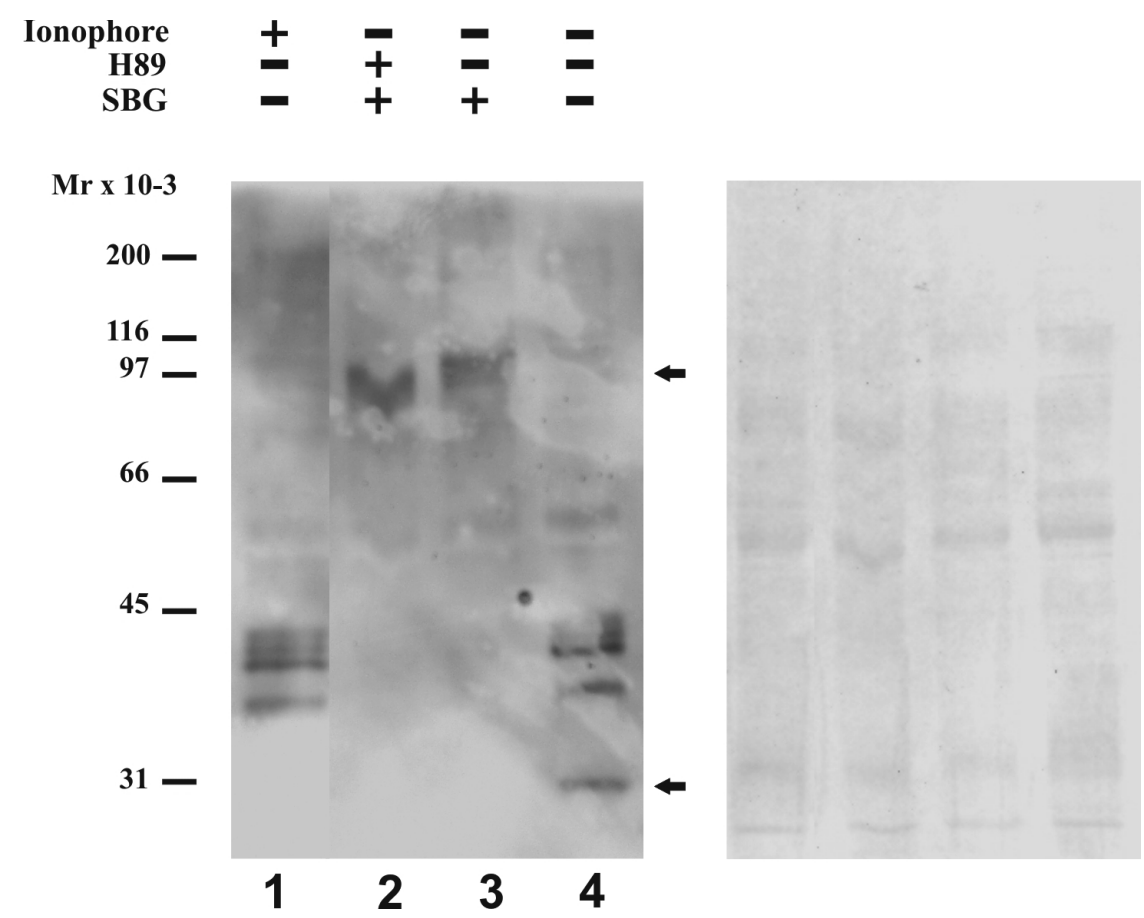

Figure 5. Phosphotyrosine content of p97 on SBG, H89 or calcium ionophore $A 23187$ treated sperm: Proteins from 1 x $10^{6}$ sperm were used for SDS-PAGE, followed by western blotting with anti-phosphotyrosine antibodies (A). Sperm were incubated in capacitating conditions in the absence (lane 4) and presence of SBG (lanes 2 and 3). Lane 2 sperm were pre-treated with H89. Lane 1 shows proteins from sperm in which acrosome reaction was induced with calcium ionophore A23187 for comparison. B- Pounceau red staining of the membrane. The arrows indicate polypeptides of apparent molecular mass $32 \mathrm{kDa}$ (p32) and $97 \mathrm{kDa}$ (p97). 
in conditions to undergo acrosome reaction are counted as capacitated. However, capacitation is a complex process that involves many metabolic and membrane associated changes, giving as a final result sperm in conditions as to undergo acrosome reaction. A variety of techniques allow the detection of changes associated with capacitation, among them CTC staining (Wang et al., 1995) shows increased membrane fluidity that occurs early in the process, well before sperm are able to proceed to acrosome reaction (Tardiff et al., 1999). In order to establish if SBG acts only over fully capacitated sperm or also on sperm in the first stages of capacitation, in this work, we analyze SBG's time course effect on sperm by CTC staining. It is interesting to note that SBG treated sperm show patterns in which the periacrosomal membrane seems to be detached or swelled, and yet are fluorescent (Fig. 2), in accordance with the morphology first found after SBG treatment by Wells and Awa staining (Teijeiro et al., 2008). This AA associated sperm resemble the pattern LCP described for human, which was

\section{anti-phosphotyrosine}
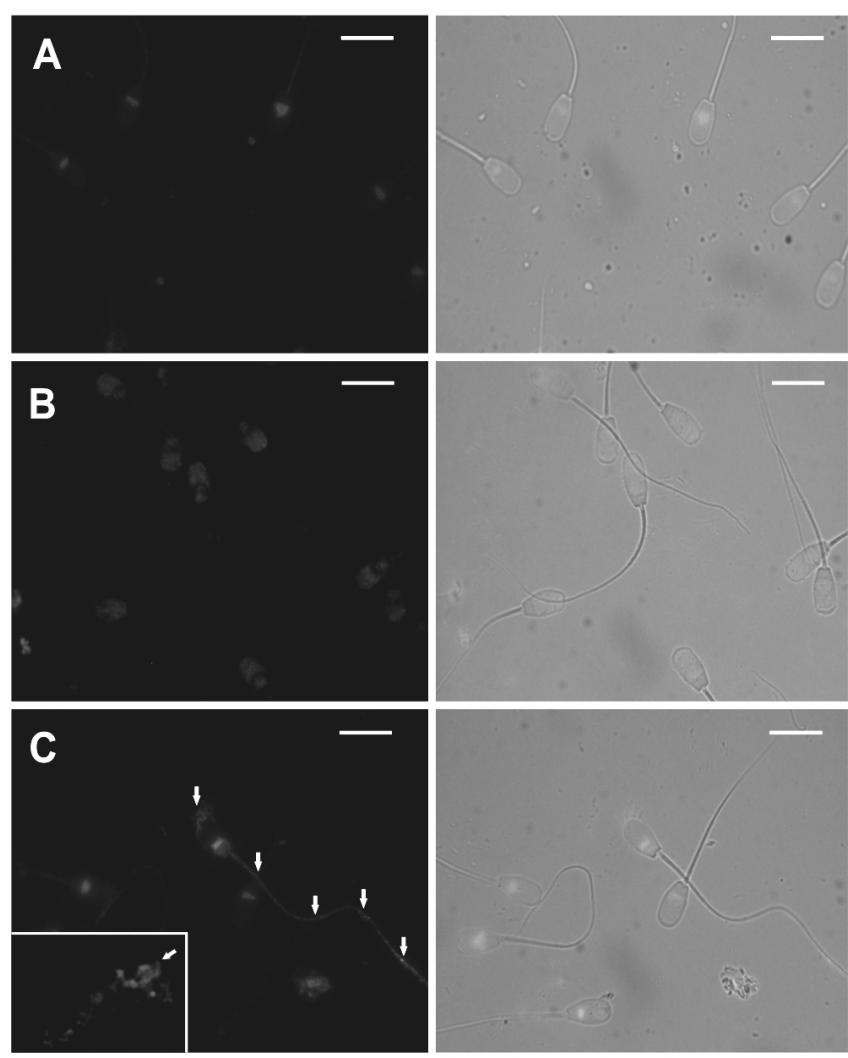

Figure 6. Immunolocalization of phosphotyrosine containing proteins in sperm: Micrographs of the patterns observed in sperm after different treatments. A- non-incubated, B- incubated in capacitating conditions, C- incubated in capacitating conditions with SBG $(150 \mu \mathrm{g} / \mathrm{ml})$; and revealed with anti-phosphotyrosine antibodies, followed by Alexa Fluor ${ }^{\circledR} 488$ conjugated antimouse immunoglobulin, inset shows detection without previous permeabilization. Merged images are shown on the right. Arrows indicate phosphorylated proteins in the fragments of detached periacrosomal membrane and flagella. Scale bar represents $10 \mu \mathrm{m}$. proposed to represent partial acrosome-reacted sperm (Perry et al., 1995).

The AA effect of SBG is first detected, for the higher concentration, concomitant with an augment of pattern $B$ (capacitated) sperm in the control (Fig. 3), suggesting that as soon as sperm begin the capacitating process, SBG may produce its effect. The slight increase of AA sperm in the control observed from this time on, may be due to spontaneous acrosome reaction of capacitated sperm, and is also seen for the lowest SBG concentration, which may be too low to produce noticeable AA effect after 40 minutes of incubation. This response is generally attributed to a degenerative process of sperm that are fully capacitated (Dapino et al., 2006). After one hour of treatment, AA was detected showing an SBG concentration dependent effect and in amounts comparable to those observed using Wells and Awa staining (Teijeiro et al., 2008), while the control showed the expected rate of pattern $B$ (capacitated) and AA sperm.

Interestingly, pattern $B$ sperm did not increase in time in SBG treated samples (Fig. 3). Also, the presence of SBG could not be detected bound to pattern B sperm (Fig. 4), but was observed on every pattern F (intact) sperm after one hour of incubation. Taken together, these results support the hypothesis that among the sperm population there is always a small amount of sperm (at least 3\%) that are refractory to SBG binding, and also a certain amount of sperm in the appropriate physiological state as to begin capacitation. When the appropriated subpopulation of sperm begins the capacitation process, at least in vitro, the presence of SBG produces AA. These would leave a small amount of CTC pattern B sperm at any time, which are probably unable of interacting with SBG. The decrease of pattern B (capacitated) found for $150 \mu \mathrm{g} / \mathrm{ml}$ of SBG after 1 hour of incubation, when AA sperm constitute almost $80 \%$ of the population, may be due to a diminution of sperm in the appropriate physiological state as to begin the capacitation process. In vivo, at pre- and peri-ovulatory stages of the porcine oestrus, only $1-5 \%$ sperm undergo capacitation in the oviduct, while a significant increase $(14 \%)$ of capacitated sperm is found in this organ at post-ovulatory oestrus (Tienthai et al., 2004). This difference has been related to changes in the oviductal fluid composition (Tienthai et al., 2004). Thus, in pre-ovulatory oestrus, interaction between oviductal SBG and sperm wouldn't cause any effect, as the gametes are immersed in a non-capacitating environment, and at the post-ovulatory stages, when capacitation is promoted by the oviductal milieu, SBG would produce AA of the remaining sperm. Considering that, at least in pig, polyspermy is thought to originate principally from increased numbers of capacitated spermatozoa reaching the site of fertilization (Hunter, 1972; Hunter, 1976; Hunter et al., 1991); that the isthmus limits the passage of spermatozoa to the upper regions of the Fallopian tubes in vivo (Hunter and Leglise, 1971; Hunter, 1973); and that sperm with acrosomal alteration or acrosome-reacted cannot bind to $\mathrm{ZP}$, excluding them for the fertilization race (Fazeli et al., 1997), the possible reduction of the number of sperm reaching the ampulla in capacitated state due to SBG's effect, could be considered, in certain manner, as a pre-fertilization polyspermy prevention mechanism in vivo.

When immunodetection of SBG was done over CTC stained sperm the glycoprotein was detected on patches on AA (and LCP-like) pattern and in pattern $\mathrm{F}$, confirming that it remains bound after producing its effect (Fig. 4D). Thus, sperm that 
suffer AA due to interaction with SBG in the lumen of the isthmus at post-ovulatory stages of oestrus would keep SBG bound at their altered acrosomal membrane. Considering that $\mathrm{ZP} 3 \alpha$ (Mr $55 \mathrm{kDa}$ ) binds to the acrosome region of acrosome-damaged or partially acrosome-reacted spermatozoa (Yonezawa et al., 2005), that Mr $55 \mathrm{kDa}$ zona pellucida component exhibits Galß1-3GalNac, as does SBG (Marini and Cabada, 2003), and that deglycosylation of Mr $55 \mathrm{kDa}$ makes $\mathrm{ZP}$ unable to trigger acrosomal reaction, it is possible that SBG bound to AA sperm would block their interaction with $\mathrm{ZP} 3 \alpha$. Reduction of the number of sperm bound to the zona may serve to reduce the incidence of polyspermy (Hunter, 1993; Killian, 2004). Thus, this could constitute another indirect pre-fertilization mechanism of polyspermy prevention by SBG, similar to what was demonstrated for oviductalspecific glycoprotein, at least in vitro (Kouba et al., 2000). This mechanism would require SBG to be ripped from the oviductal epithelium upon sperm liberation, which is plausible, given that it can be easily extracted in vitro (Marini and Cabada, 2003). Another interesting study shows that SBG is resistant to trypsin and chemotrypsin degradation (Marini and Cabada, 2003); such property would make the glycoprotein resistant to in situ degradation by enzymes liberated from the acrosome upon AA, allowing it to protect the epithelium from enzymatic damage.

It is generally accepted that sperm capacitation, motility and acrosome reaction are associated with protein kinaseA-mediated tyrosine phosphorylation of proteins (Urner and Sakkas, 2003). In boar sperm, however, the appearance of phosphorylated p32 is considered related to capacitation (Tardif et al., 2001), but its phosphorylation is independent of the cAMP/PKA pathway (Tardif et al., 2004). We have previously reported the induction of tyrosine-phosphorylation of p97 by SBG in boar sperm incubated under capacitating conditions. In this work we show that p97's phosphorylation induction by SBG is apparently also independent of PKA, as it is not affected by the inhibitor H89 (Fig. 5), which does not affect p32 phosphorylation during capacitation either (Fig. 5) (Tardif et al., 2004). Thus, an alternative mechanism seems to mediate SBG signal transduction in boar sperm, as also happens for p32 tyrosine-phosphorylation (Tardif et al., 2004). SBG produces tyrosine-phosphorylation of proteins located at the flagellum of pig sperm, and tyrosine-phosphorylation of proteins of the periacrosomal membranes that seem to remain in the attached altered periacrosomal membranes (Fig. 5). Only the last is seen when tyrosine-phosphorylated proteins are detected without permeabilization of sperm, indicating that only the periacrosomal proteins are exposed. Phosphorylated p32 is liberated/dephosphorylated from sperm upon acrosome alteration (Fig. 5-6), as well as in ionophore-induced acrosome reaction (Fig. 5). Tyrosine-phosphorylation of proteins located in the head of sperm (Fig. 6B) is characteristic of the capacitated state (Dubé et al., 2005). The phosphorylation of flagellar proteins under capacitating conditions has been shown for several mammals in association to hyperactivated motility (Mahony and Gwathney, 1999; Nassar et al., 1999; Si and Okuno, 1999) but, to the best of our knowledge, not for pigs. Further studies are needed to identify p97 and elucidate its possible mechanism of action. However, as SBG diminishes the motility of sperm (Teijeiro et al., 2008), the tyrosinephosphorylation of proteins located in the tail it promotes, seems to have the opposite effect of that reported for other mammals. Interestingly, suppression of motility produced by proteins derived from oviductal epithelial cells plasma membranes, has been considered as part of a sperm selection mechanism (Satake et al., 2006). In conclusion, we have previously proposed that SBG may interact with sperm that have begun capacitation when they arrive to the oviduct and produce acrosome rupture or, alternatively, it may be involved in sperm attachment to the oviduct and produce alteration of acrosomes in a sperm-subpopulation specific manner that may involve calcium and bicarbonate microenvironment availability (Teijeiro et al., 2008). The evidence presented in this work supports the later hypothesis. Furthermore, a possible mechanism of negative selection by SBG is suggested, based on this further analysis of its action.

\section{ACKNOWLEDGEMENTS}

We thank Veterinarian Fernando Cane for kindly providing the sperm samples and Frigorífico Paladini SA for the oviducts. This work was supported in part by UNR, and the ANPCyTBID program PICT 1284 of Argentina.

\section{REFERENCES}

ALTHOUSE GC (1997) Evaluating porcine semen for artificial insemination: standard tests. Department of Veterinary Clinical Medicine, College of Veterinary Medicine, University of Illinois (eds). Compendium on continuing education for the practicing veterinarian. pp:30-35

ARDÓN F HD, SAHIN E, BOLLWEIN H, TÖPFER PETERSEN E AND WABERSKI D (2008) Chromatin-unstable boar spermatozoa have little chance of reaching oocytes in vivo. Reproduction 135: 461-470.

BERGER T, TURNER KO, MEIZEL S, AND HEDRICK JL (1989) Zona pellucida-induced acrosome reaction in boar sperm. Biol Reprod 40:525-30.

DAPINO DG, MARINI PE AND CABADA MO (2006) Effect of heparin on in vitro capacitation of boar sperm. Biol Res 39:631-639.

DEMOTT RP, LEFEBVRE R AND SUÁREZ SS (1995) Carbohydrates mediate the adherence of hamster sperm to oviductal epithelium. Biol Reprod 52:1395-1403.

DEMOTT RP AND SUÁREZ SS (1992) Hyperactivated sperm progress in the mouse oviduct. Biol Reprod 46:779-85.

DUBÉ C, LECLERC P, BABA T, REYES MORENO C AND BAILEY JL (2005) The proacrosin binding protein, sp32, is tyrosine phosphorylated during capacitation of pig sperm. J Androl 26:519-528.

EKHLASI HUNDRIESER M, GOHR K, WAGNER A, TSOLOVA M, PETRUNKINA A AND TÖPFER PETERSEN E (2005) Spermadhesin AQN1 is a candidate receptor molecule involved in the formation of the oviductal sperm reservoir in the pig. Biol Reprod 73:536-545.

ELLINGTON JE, EVENSON DP, WRIGHT RW JR, JONES AE, SCHNEIDER CS, HISS GA AND BRISBOIS RS (1999) Higher-quality human sperm in a sample selectively attach to oviduct (fallopian tube) epithelial cells in vitro. Fertil Steril 71:924-929.

FAZELI A, HAGE WJ, CHENG FP, VOORHOUT WF, MARKS A, BEVERS MM AND COLENBRANDER B (1997) Acrosome-intact boar spermatozoa initiate binding to the homologous zona pellucida in vitro. Biol Reprod 56, 430-438.

FAZELI A, DUNCAN AE, WATSON PF AND HOLT WV (1999) Spermoviduct interaction: induction of capacitation and preferential binding of uncapacitated spermatozoa to oviductal epithelial cells in porcine species. Biol Reprod 60:879-886.

GUALTIERI R AND TALEVI R (2000) In vitro-cultured bovine oviductal cells bind acrosome-intact sperm and retain this ability upon sperm release. Biol Reprod 62:1754-1762.

GUALTIERI R AND TALEVI R (2003) Selection of highly fertilizationcompetent bovine spermatozoa through adhesion to the Fallopian tube epithelium in vitro. Reproduction 125:251-8.

GUALTIERI R, BONI R, TOSTI E, ZAGAMI M AND TALEVI R (2005) Intracellular calcium and protein tyrosine phosphorylation during the release of bovine sperm adhering to the fallopian tube epithelium in vitro. Reproduction 129(1):51-60.

GUALTIERI R, MOLLO V, DUMA G AND TALEVI R (2009) Redox control of surface protein sulfhydryls in bovine spermatozoa reversibly 
modulates sperm adhesion to the oviductal epithelium and capacitation. Reproduction 138:33-43

GWATHMEY T, IGNOTZ GG, MUELLER JL, MANJUNATH P AND SUAREZ SS (2006) Bovine seminal plasma proteins PDC-109, BSP-A3, and BSP-30-kDa share functional roles in storing sperm in the oviduct. Biol Reprod 75:501-507.

HOLT W, ELLIOTT RMA, FAZELI A, SATAKE N AND WATSON PF (2005) Validation of an strategy for studying surface-exposed proteins involved in porcine sperm-oviduct contact interaction. Reprod Fert and Dev. 17:683-692.

HUNTER RH (1972) Local action of progesterone leading to polyspermic fertilization in pigs J Reprod Fertil 31:433-444.

HUNTER RH (1973) Polyspermic fertilization in pigs after tubal deposition of excessive numbers of spermatozoa. J Exp Zool 183:57-63.

HUNTER RH (1976) Sperm-Egg interactions in the pig: monospermy, extensive polyspermy, and the formation of chromatin aggregates. J Anat 122:43-59.

HUNTER RH (1981) Sperm transport and reservoirs in the pig oviduct in relation to the time of ovulation. J Reprod Fertil 63:109-117.

HUNTER RH (1993) Sperm:egg ratios and putative molecular signals to modulate gamete interactions in polytocous mammals. Mol Reprod Dev 35:324-377.

HUNTER RH AND LEGLISE PC (1971) Polyspermic fertilization following tubal surgery in pigs, with particular reference to the role of the isthmus. J Reprod Fertil 24:233-246.

HUNTER RH AND NICHOL R (1983) Transport of spermatozoa in the sheep oviduct: preovulatory sequestering of cells in the caudal isthmus. J Exp Zool 228:121-128.

HUNTER RH, FLECHON B AND FLECHON JE (1991) Distribution, morphology and epithelial interactions of bovine spermatozoa in the oviduct before and after ovulation: a scanning electron microscope study. Tissue Cell. 23:641-56.

IGNOTZ GG, CHO MY AND SUÁREZ SS (2007) Annexins are candidate oviductal receptors for bovine sperm surface proteins and thus may serve to hold bovine sperm in the oviductal reservoir. Biol Reprod 77:906-913.

KAN FW AND ESPERANZATE PW (2006) Surface mapping of binding of oviductin to the plasma membrane of golden hamster spermatozoa during in vitro capacitation and acrosome reaction. Mol Reprod Dev 73:756-766.

KILLIAN GJ (2004) Evidence for the role of oviduct secretions in sperm function, fertilization and embryo development. Anim Reprod Sci 8283:141-53

KOUBA AJ, ABEYDEERA LR, ÁLVAREZ IM, DAY BN AND BUHI WC (2000) Effects of the porcine oviduct-specific glycoprotein on fertilization, polyspermy, and embryonic development in vitro. Biol Reprod 63:242-250.

LAEMMLI UK (1970) Cleavage of structural proteins during the assembly of the head of bacteriophage T4. Nature 227:680-685.

LEFEBVRE R AND SUÁREZ SS (1996) Effect of capacitation on bull sperm binding to homologous oviductal epithelium. Biol Reprod 54:575-582.

LEFEBVRE R, LO MC AND SUÁREZ SS (1997) Bovine sperm binding to oviductal epithelium involves fucose recognition. Biol Reprod 56:1198-1204.

MAHONY MC AND GWATHMEY TY (1999) Protein tyrosine phosphorylation during hyperactivated motility of cynomolgus monkey (Macaca fascicularis) spermatozoa. Biol Reprod 60:1239-1243

MANASKOVA P, PEKNICOVA J, ELZEINOVA F, TICHA M AND JONAKOVA V (2007) Origin, localization and binding abilities of boar DQH sperm surface protein tested by specific monoclonal antibodies. J Reprod Immunol 74:103-113.

MARINI PE AND CABADA MO (2003) One step purification and biochemical characterization of a spermatozoa-binding protein from porcine oviductal epithelial cells. Mol Reprod Dev 66:383-390.

MBURU JN, RODRÍGUEZ MARTÍNEZ H AND EINARSSON S (1997) Changes in sperm ultrastructure and localization in the porcine oviduct around ovulation. Anim Reprod Sci 47:137-148

MELÉNDREZ C, MEIZEL S, AND BERGER, T (1994) Comparison of the ability of progesterone and heat solubilized porcine zona pellucida to initiate the porcine sperm acrosome reaction in vitro. Mol Reprod Dev 39:433-438

MOTULSKY H (1995) Intuitive biostatistics. New York: Oxford University Press. pp:118-127

NASSAR A, MAHONY M, MORSHEDI M, LIN MH, SRISOMBUT C AND OEHNINGER S (1999) Modulation of sperm tail protein tyrosine phosphorylation by pentoxifyline and its correlation with hyperactivated motility. Fertil Steril 71:919-923.
ORIHUELA PA, ORTIZ ME AND CROXATTO HB (1999) Sperm migration into and trough the oviduct following artificial insemination at different stages of estrous cycle in the rat. Biol Reprod 60:908-913

PACEY AA, DAVIES N, WARREN MA, BARRATT CL AND COOKE ID (1995) Hyperactivation may assist human spermatozoa to detach from intimate association with the endosalpinx. Hum Reprod 10:2603-2609.

PARRISH JJ, SUSKO PARRISH J, WINER MA AND FIRST NL (1988) Capacitation of bovine sperm by heparin. Biol Reprod 38:1171-1180.

PÉREZ FA, ROMA SM, CABADA MO AND MARINI PE (2006) Sperm binding glycoprotein is differentially present surrounding the lumen of isthmus and ampulla of the pig's oviduct. Anat Embryol 211:619-624.

PERRY RL, NAEENI M, BARRAT CLR, WARREN M AND COOKE MA (1995) A time course study of capacitation and the acrosome reaction in human spermatozoa using a revised chlortetracycline pattern classification. Fertil Steril 64:150-159.

PETRUNKINA AM, FRIEDRICH J, DROMMER W, BICKER G, WABERSKI D AND TOPFER PETERSEN E (2001) Kinetic characterization of the changes in protein tyrosine phosphorylation of membranes, cytosolic $\mathrm{Ca} 2+$ concentration and viability in boar sperm populations selected by binding to oviductal epithelial cells. Reproduction 122:469-480.

RABILLOUD T, VUILLARD L, GILLY C AND LAWRENCE JJ (1994) Silverstaining of proteins in polyacrylamide gels: a general overview. Cell $\mathrm{Mol}$ Biol 40:57-75.

SATAKE N, ELLIOTT RMA, WATSON PF AND HOLT WV (2006) Sperm selection and competition in pigs may be mediated by the differential motility activation and suppression of sperm subpopulations within the oviduct. J Exp Zool 209:1560-1572.

SI Y AND OKUNO M (1999) Role of tyrosine phosphorylation of flagellar proteins in hamster sperm hyperactivation. Biol Reprod 61:240-246.

SMITH TT AND YANAGIMACHI R (1991) Attachment and release of spermatozoa from the caudal isthmus of the hamster oviduct. J Reprod Fertil 91:567-573.

SUÁREZ SS (1987) Sperm transport and motility in the mouse oviduct: observations in situ. Biol Reprod 36:203-210.

SUÁREZ SS (2001) Carbohydrate-mediated formation of the oviductal sperm reservoir in mammals. Cells Tissues Organs 168:105-112.

TARDIF S, SIRARD M, SULLIVAN R AND BAILEY J (1999) Identification of capacitation-associated phosphoproteins in porcine sperm electroportated with ATP- $\gamma$-32 P. Mol Reprod Dev 54:292-302.

TARDIF S, DUBÉ C, CHEVALIER S AND BAILEY JL (2001) Capacitation is associated with tyrosine phosphorylation and tyrosine kinase-like activity of pig sperm proteins. Biol Reprod 65:784-792

TARDIF S, LEFEVRE L, GAGNON C AND BAILEY J (2004) Implication of cAMP during porcine sperm capacitation and protein tyrosine phosphorylation. Mol Reprod Develop 69:428-435

TEIJEIRO JM, CABADA MO AND MARINI PE (2008) Sperm binding glycoprotein (SBG) produces calcium and bicarbonate dependent alteration of acrosome morphology and protein tyrosine phosphorylation on boar sperm. J Cell Biochem 103:1413-1423.

TEIJEIRO JM, IGNOTZ GG AND MARINI P (2009) Annexin A2 is involved in pig (Sus scrofa) sperm-oviduct interaction. Mol Reprod Dev 76:334-341

THOMAS PG, BALL BA, MILLER PG, BRINSKO SP AND SOUTHWOOD L (1994) A subpopulation of morphologically normal, motile spermatozoa attach to equine oviductal epithelial cell monolayers. Biol Reprod 51:303-309.

TIENTHAI P, JOHANNISSON A AND RODRÍGUEZ-MARTÍNEZ H (2004) Sperm capacitation in the porcine oviduct. Anim Reprod Sci 80:131-146.

TÖPFER PETERSEN E, EKHLASI HUNDRIESER M AND TSOLOVA M (2008) Glycobiology of fertilization in the pig. Int J Dev Biol 52:717-736

URNER F AND SAKKAS D (2003) Protein phosphorylation in mammalian spermatozoa. Reproduction 125:17-26

WAGNER A, EKHLASI HUNDRIESER M, HETTEL C, PETRUNKINA A, WABERSKI D, NIMTZ M AND TOPFER PETERSEN E (2002) Carbohydrate-based interactions of oviductal sperm reservoir formation-studies in the pig. Mol Reprod Dev 61:249-257.

WANG WH, ABEYDEERA LR, FRASER LR AND NIWA K (1995) Functional analysis using chlortetracycline fluorescence and in vitro fertilization of frozen-thawed ejaculated boar spermatozoa incubated in a protein-free chemically defined medium. J Reprod Fertil 104:305-313.

YONEZAWA N, AMARI S, TAKAHASHI K, IKEDA K, IMAI FL, KANAI S, KIKUCHI K AND NAKANO M (2005) Participation of the nonreducing terminal beta-galactosyl residues of the neutral N-linked carbohydrate chains of porcine zona pellucida glycoproteins in sperm-egg binding. Mol Reprod Dev 70:222-227. 
